\title{
MECHANISM AND ACTIVITY SPECTRUM OF MICROBIOLOGICAL PREPARATION BATSIKOL WITH PHYTOPROTECTIVE ACTION
}

\section{S.D. GRISHECHKINA}

All-Russian Research Institute for Agricultural Microbiology, Federal Agency of Scientific Organizations, 3, sh. Podbel'skogo, St. Petersburg, 196608 Russia, e-mail svetagrishechkina@mail.ru

Acknowledgements

Supported by Ministry of Education and Sciences of the Russian Federation (Agreement No 14.604.21.0024, RFMEFI60414X0024).

Received June 17, 2015

\section{Abstract}

Various groups of agents are involved in biological crop protection to control pests and diseases. Of them, Bacillus genus possessing activity against harmful insects and phytopathogens is most promising and widely used. In this, the biologicals based on Bacillus thuringiensis (Bt) dominate. More than 70 varieties of $\mathrm{Bt}$ have been identified. These bacteria can survive for a long time after treatment. Preparations based on three Bt serovars (A, B, C) are mostly used for insects' biocontrol. Serovar A Bt subspecies can form crystal endotoxins which are active against Lepidoptera; serovar B Bt subspecies attack the larvae of mosquitoes and black flies, and phytophagous Diptera; and serovar $\mathrm{C}$ Bt subspecies are active against Coleoptera beetles. A new serovar F (fungi) of this bacillus was identified. Physiological and biochemical properties of Bacillus thuringiensis provide the assimilation of nutrient substrates and antibiosis against biocenosis partners. Batsikol, the biological preparation based on $B$. thuringiensis var. darmstadiensis $\left(\mathrm{H}_{10}\right)$ with entomopathogenic action, was created at All-Russian Research Institute of Agricultural Microbiology (St. Petersburg). Batsikol contains components of culture liquid, spores, insecticidal and fungicidal exo- and endotoxins, due to which it possesses multifunctional properties. The article presents the mechanisms of entomopathogenic and antifungal action of microbial preparations based on Bt. Results of testing Batsikol effectiveness against various pests and diseases in field trials and vegetation experiments are shown. Liquid form of biological product was used in the study (spore titer of $3.5 \times 10^{9} / \mathrm{ml}$ ). Field and vegetation tests were carried out in 1994-2013 in different regions of Russia (Leningrad, Novosibirsk, Volgograd region, North Ossetia, Stavropol and Primorsky regions). Batsikol was sprayed against phytophagous pests on vegetating plants. The efficacy against pests varied from 50 to $100 \%$. Different modes of application against phytopathogen were tested according to the type of parasitism and environmental characteristics of fungi (i.e., spraying, irrigation, seed treatment). In field experiments the efficacy of spraying strawberry plants against gray mold was 60-74\%. Soil watering was used against Fusarium wilt on tomatoes and flax with efficacy of $74-87 \%$ and $34-42 \%$, respectively. When seeds were treated prior to sowing the efficacy was $66-71 \%$ in case of soaking barley seeds against root rot, and 40-45\% while soaking potato tubers against damping-off. Based on the tests conducted with Batsikol in different regions of Russia, the spectrum of its activities against wide range of phytophagous pests and pathogenic fungi was revealed on different crops. The obtained data expand the understanding of Bt biology and, in particular, the action spectrum against various pests and diseases dangerous for many cultivated plants. Presented materials allow considering Bacillus thuringiensis as the basis of microbiological preparations with a multifunctional activity. The obtained data will allow expanding the scope of its application, and it will help to improve ecological situation.

Keywords: Bacillus thuringiensis, Batsikol, phytophagous insects, phytophathogenic fungi, biological efficiency.

Various groups of agents are involved in biological crop protection to control pests and diseases. Currently, much attention is paid to the bacteria with phytoprotective function. Of them, the Bacillus genus is most promising and widely used for creation of biological preparations. They possess activity against harmful phytophague insects and phytopathogens [1-14]. The biologicals based on Bacillus thuringiensis $(\mathrm{Bt})$ are predominant. In world practice, $\mathrm{Bt}$ is used as a 
safe insecticidal agent, its share in the market of biopesticides is about 90-95\%.

High adaptive capacity of aerobic spore-forming thuringiensis bacteria under various extreme conditions determine their widespread in nature. The greatest number of bacilli is isolated from the soil, they are often found in water and extracted from sick and dead insects. Over $70 \mathrm{Bt}$ varieties greatly effective against Lepidoptera, Coleoptera, Diptera and Hymenoptera phytophages have been identified. Bt bacteria can survive for a long time after treatment of plants. They have high selectivity of action, are effective against target objects, safe for human, warm blooded animals and beneficial organisms [15]. Antifeedant, teratogenic and dereproductive features provide their high biological effectiveness. Bt-based products are processible in manufacture and use.

Preparations based on three Bt serovars are mostly used for insect biocontrol in agrocenoses. Bt subspecies of serovar A form endotoxin crystals that are most active against lepidopterous insects (Lepidoptera). They are producers of drugs such as Bitoxybacillin (Bt var. thuringiensis), Dendrobacillin (Bt var. dendrolimus), Entobacterin (Bt var. galleria), Lepidocide (Russia), DIPel (USA), Bactospeine (Bt var. kurstaki) (France), etc. Over 70 insect species are sensitive to this serovar. Bt subspecies of serovar B (Bt var. israelensis) are used as producers of larvicidal biologics, such as Bactoculicide, Bacticide (Russia), Bactimos (France), Teknar (Switzerland), Vectobac (USA), etc., that attack the larvae of mosquitoes and black flies, and phytophagous mosquitoes (rice and champignon mosquitoes) (Diptera). Bt subspecies of serovar C (Bt var. tenebrionis, Bt var. darmstadiensis) are active against beetles (Coleoptera), are used as producers of Decimide, Colorado, Batsikol (Russia), Novodor (Denmark), and other biological preparations [2]. A new serovar F (fungi) [1] of this bacillus has been identified.

Batsikol, an entomopathogenic biological preparation based on $B$. thuringiensis var. darmstadiensis $\left(\mathrm{H}_{10}\right)$ containing the components of liquid culture, spores, insecticidal and fungicidal exo- and endotoxins, due to which it possesses multifunctional properties, was created at All-Russian Research Institute of Agricultural Microbiology (ARRIAM). The following Batsikol forms are available: dry powder, paste and liquid form.

Batsikol is similar to Bitoxybacillin (BTB) in its purpose and effectiveness. The latter possesses insecticidal effect and is active against a wide range of pests phytophages. It is recommended against cabbage moth (Mamestra brassicae L.), large and small whites (Pieris brassicae, $P$ rapae L.) caterpillars in cabbage; meadow moth (Loxostege sticticalis L.) caterpillars in beet, alfalfa, sunflower, carrot, and cabbage crops; grape berry moth (Polychrosis botrana Schiff.) in grapes; corn earworm (Heliothis zea F.), turnip moth (Scotia segetum Schiff.), and lappet moth (Laphigma exigua Hb.) caterpillars in cotton plants; apple ermine moth and small ermine moth (Yponomeuta malinellus Zell., $Y$. padellus L.), brown oak (Aporia crataegi L.), fall webworm (Hyphantria cunea Drury) caterpillars in fruit trees and berry plants; brown oak tortrix (Archips crataegana Hb.), gypsy moth and lackey moth (Ocneria dispar L. and Malacosoma neustria L.), winter moth (Operophtera brumata Cl.), mottled umber (Erannis defoliaria L.), brown-tail moths (Euproctis chrysorrhoea L., E. karghalica M.) in fruit and woody plants, Colorado beetle larvae (Leptinotarsa decemlineata Say) in potatoes, tomatoes, aubergine; spider mite (Tetranychus urticae Koch) in cucumbers in greenhouses, small gooseberry sawfly (Pristiphora pallipes Lep.), common gooseberry sawfly (Pteronidea ribesii Scop.) in currants, gooseberries and other pests [2]. In addition, BTB is active against jewel beetle (Agrilus ribesi Schaefer) [16]. Extensive BTB testing conducted in various regions of the Russian Federation and the CIS (Krasnodar and Stavropol' Territories, North Ossetia, Lenin- 
grad region, Republic of Crimea, Transcarpathia, Belarus, Lithuania) showed its high efficiency (from 80 to $100 \%$ ) [2].

Both pathogen and insect characteristics should be taken into account for the successful use of biologics for protection measures. In this regard, it is important to know the mechanism of their interrelations as well as of their relations with the environment. Like other bacilli, B. thuringiensis possesses physiological and biochemical features to ensure the absorption of nutrient substrates and antibiosis against biocenosis partners. Bacteria of the genus Bacillus are characterized by polyenzymatic features. Various enzymes of the class of hydrolases are found in them which results in simultaneous activities against pest insects and pathogenic fungi [1, 17-19].

Bt effect on pests results from its toxicity to insects, entomopathogenic and metatoxic effects due to the presence of crystals of endotoxin, exotoxin, phospholipase $\mathrm{C}$ and spores. This set of virulence factors is active against different insect species in varying degrees and in varying combinations. Bacteria cause diseases that are accompanied by septicemia, the severe lesions, in which the hemolymph and its phagocytic and non-specific immune mechanisms are no longer able to suppress the proliferation of microorganisms that penetrate it continuously. Cells of infected tissues are broken and the large quantity of parasitic bacteria enter hemolymph thus causing septicemia. Bacteria penetrate the intestinal epithelium where they proliferate rapidly and cause the insect death [2].

The mechanism of Bt antifungal action is linked to a number of factors. Bacteria produce and excrete lytic enzymes into the external medium, particularly protease and chitinase that lyse the cell walls of phytopathogenic fungi [20-24]. With lysis, the content of fungal hyphae becomes the source of power and energy for the bacilli. Moreover, bacilli can produce antibiotics that have a depressing effect against fungi [25].

Recently, much attention is given to the research related to the formation of cyclic lipopeptide antibiotics by the Bacillus bacteria; these antibiotics are responsible for the antagonistic effect [26-32].

Effect of $B$. subtilis on Fusarium oxysporum is explained by the combined effect of mycolitic enzymes and antibiotic substances [33]. Some authors suggest a link between the antibiotic activity and $\delta$-endotoxin; perhaps, the $B$. thuringiensis var. thuringiensis antifungal effect is due to the disconnection of oxidative phosphorylation and respiration processes in the target objects [34].

Significant crop losses due to pests and diseases combined with the need for environmentally friendly products make the use of microbiological preparations extremely important. However, compared to chemical pesticides, their assortment is smaller, therefore it is necessary to create and use the new formulation.

Our research made it possible to estimate the spectrum of action and to identify the effectiveness of the Batsikol biopreparation developed in ARRIAM against mass pests, especially phytophage coleopteran pests (Coleoptera) [35], and against the phytopathogens that cause plant diseases [36], which extends the possibilities of its application.

In this paper, we summarized the results of the study of Batsikol efficiency against pests and phytopathogens in a number of crops in various areas and at different cultivation technologies.

Technique. Field and pot tests were performed in 1994-2013 in different regions of Russia. Liquid form of insecticidal biological preparation Batsikol (ARRIAM) was used in the study (spore titer of $3.5 \times 10^{9} / \mathrm{ml}$ ). Experiments were performed in 3 replicates.

Batsikol activity against Colorado potato beetle (Leptinotarsa decemlineata Say) was studied in potatoes (Nevsky, Lugovskoi, Elizaveta varieties) at 
the farms of Leningrad and Novosibirsk regions. Potato planting area of $200 \mathrm{~m}^{2}$ infected with Colorado potato beetle was sprayed with the preparation at the rate of 12-15 1/ha and working fluid flow of $400 \mathrm{l} / \mathrm{ha}$. Counting was performed with 25 plants selected along the area diagonal prior to treatment and at posttreatment days 5 to 10 .

The plants of the strawberry variety Tsarskoselskaya were sprayed during budding in Leningrad Region in the plots of $100 \mathrm{~m}^{2}$ area. The rate of the preparation use was $15 \mathrm{l} / \mathrm{ha}$. Buds infected with strawberry blossom weevil (Anthonomus rubi Hbst.) were counted prior to the treatment and at posttreatment days 10 and 20 in 25 plants. Berries infected with grey mould were evaluated at the day 20.

Preparation efficiency (12 1/ha) against cruciferous flea beetles (Phyllotreta) and cabbage leaf beetle (Phaedon cochleariae F.) was studied in rutabaga, rape, mustard, and cabbage in Leningrad, Novosibirsk, and Volgograd regions in the plots of $50 \mathrm{~m}^{2}$ area. Counting was performed prior to treatment and at the post-treatment days 5 and 10;20 plants were examined, and the percentage of occupancy was calculated.

Carrot was treated (15 l/ha) against carrot psyllid (Trioza apicalis Frst.) at the plots of $10 \mathrm{~m}^{2}$ (counts prior to the treatment and at the post-treatment day 10 in 20 plants).

Raspberry plants were treated with batsikol (15 1/ha) against raspberry mite (Eriophyes gracillis Nal.). Mites were counted before and after treatment in the samples of 10-30 leaves.

Flower crops were sprayed (20 1/ha) against thrips (Thysanoptera) in greenhouses. Percentage of occupied plants was calculated prior to treatment and at day 10 after treatment.

Batsikol activity (20 1/ha) was tested in buckwheat Emerald variety in Primorsky Territory (Ussuriisk) against buckwheat weevil (Rhinoncus sibiricus Faust). Vegetating plants were treated. Leaf infection in the phase of germination and stem infection during flowering and before harvesting was registered.

In estimating Batsikol efficacy against harmful fungi, application techniques appropriate to the parasitism type and environmental pathogen characteristics were used. Vegetating plants of strawberry Tsarskoselskaya variety were treated with Batsikol (15 1/ha) against gray mold (Botrytis cinerea), the distribution of which was assessed by the number of infected berries. Soil infected with pathogen (Fusarium oxysporum) was watered with the preparation at a rate of $100 \mathrm{ml} / \mathrm{kg}$ against fusarium wilt of tomatoes and flax. The efficacy of pre-sowing treatment was studied in flax against fusarium wilt, in barley against Helminthosporium root blight (Bipolaris sorokiniana) and in potatoes against rhizoctoniosis (Rhizoctonia solani). Seeds were soaked in the preparation for 3 hours. Artificial infections were created in accordance with the guidelines [37, 38].

Proportion $(\mathrm{P})$ and severity $(\mathrm{R})$ of the disease was evaluated according to the formula [39]: $\mathrm{P}=\mathrm{A} \times 100 / \mathrm{N}$, where $\mathrm{P}$ is a proportion of infected plants, $\%, \mathrm{~A}$ is the number of infected plants, $\mathrm{N}$ is the total number of plants in the samples; $\mathrm{R}=\Sigma(\mathrm{a} \times \mathrm{B}) / \mathrm{N} \times \mathrm{K}$, where $\mathrm{R}$ is severity of the disease, \%; $\Sigma(\mathrm{a} \times \mathrm{b})$ is a sum of diseased plants number (a) multiplied by the corresponding score of disease development (b); $\mathrm{N}$ is a total number of recorded plants; $\mathrm{K}$ means the highest infection scale score.

Fusarium wilt infection was recorded in flax by N.I. Loshakova et. al scale [40], in tomatoes by S.D. Grishechkina et. al [36]. Prevalence of barley plants with root rot was evaluated on the VIZR scale (All-Russian Institute of Plant Protection, St. Petersburg) [41]. Rhizoctoniosis infection in potato tubers was recorded according to the guidelines [42]. 
Results. Batsikol effect on Colorado potato beetle has been identified earlier. Treatment of potatoes in Stavropol' and Krasnodar territories, in Volgograd and Leningrad regions and in North Ossetia demonstrated high (to 96$100 \%$ ) activity against this pest (2).

Batsikol showed its activity against dangerous mass pests, such as cruciferous fleas of Phyllotreta genus [43], oriental mustard leaf beetle Colaphellus hoefti Men., flea beetle Phyllotreta vittula Redt., pollen beetle Meligethes aeneus F., cabbage leaf beetle Phaedon cochleariae F., elm leaf beetle Xanthogaleruca luteola Müller [44], cereal leaf beetle Oulema melanopus L., shield bugs (Eurydema), scale insects (Diaspididae) [2], strawberry blossom weevil Anthonomus rubi Hbst. [45], buckwheat weevil Rhinoncus sibiricus Faust [46], carrot psyllid Trioza apicalis Frst., raspberry mite Eriophyes gracilis Nal. [47], and thrips Thysanoptera [48] (Table).

Biological efficacy of the Bacillus thuringiensis var. darmstadiensis-based liquid Batsikol form $\left(\mathrm{H}_{10}\right)$ developed by the All-Russian Research Institute of Agricultural Microbiology (St. Petersburg) against pest phytophages in various crops (1994-2013)

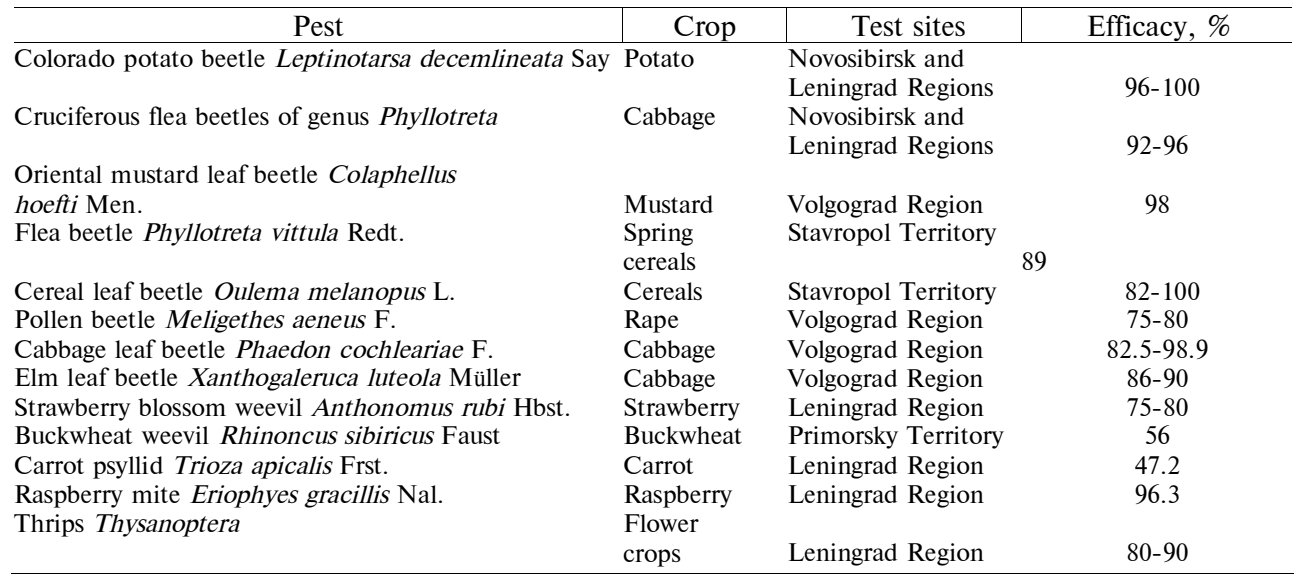

In the study of the product activity against strawberry blossom weevil, its effect on the gray mold pathogen Botrytis cinerea Pers. was found in strawberries. Earlier, we observed antifungal Batsikol activity against a number of pathogenic fungi in in vitro experiments. With supplementing medium with the product at the concentration of $10 \%$, we observed $100 \%$ inhibition of the growth of fungi Botrytis cinerea Pers. colonies, $80 \%$ inhibition in Pythium sp., $70 \%$ in Bipolaris sorokiniana (Sacc.) Shoemaker, $52 \%$ in Verticillium dahliae Kleb., $42 \%$ in Rhizoctonia solani Kuhn, $51 \%$ in Fusarium avenaceum (Fr.) Sacc., $43 \%$ in F. oxysporum Schlecht., and $26 \%$ in F. solani App. et Wr. [49].

The product activity against a number of phytopathogens was confirmed in field and pot experiments. The efficacy of spraying strawberry plants against gray mold was 60-74 \% [44]; with soil watering against Fusarium wilt it was 74$87 \%$ in tomatoes [50] and 34-42\% in flax [51]; efficacy was 66-71\% in case of soaking barley seeds against root rot [52] and 40-45\% with the treatment of potato tubers against rhizoctoniosis [53].

Thus, our results expand the understanding of Bacillus thuringiensis biological features and, in particular, its action spectrum against various pests and dangerous pathogens for many cultivated plants. Along with insecticidal activity, Batsikol possesses antifungal activity as well that has a technological perspective. We found its activity against strawberry blossom and buckwheat weevils, cruciferous flea beetles, carrot psyllid, raspberry mite, thrips, and pathogens Botrytis cinerea Pers., Pythiim sp., Bipolaris sorokiniana (Sacc.) Shoemaker, Verticillium dahliae Kleb., Rhizoctonia solani Kuhn, and Fusarium avenaceum (Fr.) Sacc., 
F. oxysporum Schlecht, F. solani App. et Wr. Batsikol inclusion in the list of microbiological agents can expand the range of biological plant protection products and their scope, which will contribute to the production of ecologically pure food and to the environment.

\section{R E F E R E N C E S}

1. S mi r nov O.V., Gris he c h k i n a S.D. Sel'skokhozyaistvennaya biologiya [Agricultural Biology], 2011, 3: 123-126.

2. Kandybin N.V., P a ty k a T.I., Ermolova V.P., P a t y k a V.F. Mikrobiokontrol' chislennosti nasekomykh i ego dominanta Bacillus thuringiensis /Pod redaktsiei N.V. Kandybina [Microbiocontrol of insects, and Bacillus thuringiensis as a predominate agent]. St. Petersburg-Pushkin, 2009.

3. Shte rnshis M.V. V sbornike nauchnykh tudov: Mikrobnye biotekhnologii: fundamental'nye i prikladnye aspekty. Tom 5 [In: Microbilal biotechnologies: fundamental and practical aspects. V. 5]. Minsk, 2013: 394-410.

4. Bakhvalov S.A., Tsvetkova V.P., Shpatova T.V., Shternshis M.V., $\mathrm{G}$ ri s h e ch k i n a S.D. Sibirskii ekologicheskii zhurnal, 2015, 4: 643-650.

5. Pola nczyk R.A., Pires d a Silva R.F., Fi u za L.M. Effectiveness of Bacillus thuringiensis against Spodoptera frugipera (Lepidoptera: Noctuidae). Brazil. J. Microbiol., 2000, 31: 165-167 (doi: 10.1590/S1517-83822000000300003).

6. Zhong C.H., E 11 a r D.J., B ishop A., Johnson C., Lin S.S., Hart E.R. Characterization of Bacillus thuringiensis $\delta$-endotoxin which is toxic to insects in three orders. J. Invert. Pathol., 2000, 76: 131-139.

7. Yoshida S., Hiradate S., Tsulamoto T., Hat akeda K., Shirat a A. Antimicrobial activity of culture filtrate of Bacillus amyloligauefaciens Rc-2 isolated from mulberry leaves. Phythopathol., 2001, 91: 181-187.

8. Kna a N N., Roh r A., Fiuz a L. In vitro effect of Bacillus thuringiensis strains and Cryproteins in phytopathogenic fungi of paddy rice-field. Brazil. J. Microbiol., 2007, 38(3): 526-530 (doi: 10.1590/S1517-83822007000300027).

9. Mojica-Marin V., Luna-Olvera H., Sandoval-Coronado C., PereyraAlferes B., Morales-Ramos L., Hernandez-Luna C., Alvarado-Gome z O. Antagonistic activity of selected strains of Bacillus thuringiensis against Rhizoctonia solani of chili pepper. Afr. J. Biotechnol., 2008, 7(9): 1271-1276.

10. Eswarap ri y a B., Go pals a my B., Ka m e s wa ri B., Me e ra R., Devi P. Insecticidal activity of Bacillus thuringiensis IBt-15 strain against Plutella xycostella. Int. J. Pharm Tech Res., 2010, 2(3): 2048-2053.

11. H e y d a ri A., P e s s a ra kli M. A review on biological control of fungal plant pathogens using microbial antagonists. J. Biol. Sci., 2010, 1(4): 273-290 (doi: 10.3923/jbs.2010.273.290).

12. Pane C., Villecco D., Campanile F., Zaccardelli M. Novel strains of Bacillus isolated from compost and compost-amended soils as biological control agents against soil-borne phytopathogenic fungi. Biol. Sci. Technol., 2012, 22(12): 1373-1388 (doi: 10.1080/09583157.2012.729143).

13. A k ram W., Mahboob A., J aved A. Bacillus thuringiensis strain 199 can induce systemic resistance in tomato against Fusarium wilt. Eur. J. Microbiol. Immunol., 2013, 3: 275280 (doi: 10.1556/EuJMI.3.2013.4.7).

14. Ta o A., Pang F., Huang S., Yu G., Li B., Wang T. Characterization of endophytic Bacillus thuringiensis strains isolated from wheat plants as biocontrol agents against wheat flag smut. Biocontrol Sci. Tecnol., 2014, 24(8): 901-924 (doi: 10.1080/09583157.2014.904502).

15. S i e g e 1 J.P. The mammalian safety Bacillus thuringiensis based insecticides. J. Invert. Pathol., 2001, 77: 13-21 (doi: 10.1006/jipa.2000.5000).

16. Z e in a lov A.S., Chu rilin a T.N. Plodovodstvo i yagodovodstvo Rossii (Moscow), 2012, 2(1): 192-199.

17. Los eva O., Ibrahim M., Candas M., Kolle r C.N., Bau e r L.S., Bulla L.A. Changes in protease activity and Cry3Aa toxin binding in the Solorado potato beetle: implications for insect resistance to Bacillus thuringiensis toxins. Insect Biochem. Mol. Biol., 2002, 32: 567-577 (doi: 10.1016/S0965-1748(01)00137-0).

18. Wag ne r W., M öh rle n F., S c h n e t t e r W. Characterization of the proteolytic enzymes in the midgut of the European Cockchafer, Melolontha melolontha (Coleoptera: Scarabaidae). Insect Biochem. Mol. Biol., 2002, 32: 803-814 (doi: 10.1016/S0965-1748(01)00167-9).

19. Saguez J., Hainez R., Cherqui A., Van Wuytswinkel O., Jeanpierre H., Lebon G., Noiraud N., Beaujean A., Jouanin L., Laberche J.-C., Vin c e n t C., Giordanengo P. Unexpected effects of chitinases on the peach-potato aphid (Myzus persicae Sulzer) when delivered via transgenic potato plants (Solanum tuberosum Linne) and in vitro. Transgenic Research, 2005, 14: 57-67 (doi: 10.1007/s11248-004-3100-4).

20. Reyes-Ramirez A., Escudero-Abarca B.I., Aguilar-Uscanga G., Hay- 
wa rd - J o n e s P.M., B a rb o z a - C o ro n a J.E. Antifungal activity of Bacillus thuringiensis chitinase and its potential for the biocontrol of phytopathogenic fungi in soybean seeds. J. Food Sci., 2004, 69(5): M131-M134 (doi: 10.1111/j.1365-2621.2004.tb10721.x).

21. Xi a o L., X i e C.C., C a i J., Li n Z.J., C h e n Y.H. Identification and characterization of chitinase producing Bacillus slowing significant antifungal activity. Cur. Microbiol., 2009, 58(5): 528 (doi: 10.1007/s00284-009-9363-5).

22. S e o D.J., Nguy e n D.M., S o n g Y.S., J ung W.J. Induction of defense response against Rhizoctonia solani in cucumber plant by endophytic bacterium Bacillus thuringiensis GS1. $J$. Microbiol. Biotechnol., 2012, 22(3): 407-415 (doi: 10.4014/jmb.1107.07027).

23. Martinez-Absalón S., Rojas-Solís D., Hernandez-León R., Prieto-Barajas C., Orozco-Mosqueda M., Peña-Cabriales J., Sakuda S., Valencia-Cantero E., S a n t o y o G. Potential use and mode of action of the new strain Bacillus thuringiensis UM96 for the biological control of the grey mould phytopathogen Botrytis cinerea. Biocontrol Sci. Technol., 2014, 24(12): 1349-1362 (doi: 10.1080/09583157.2014.940846).

24. Yu G.Y., S incla i r J.B., Hartman G.L., B e rtagnolli B.L. Production of iturin A by Bacillus amyloliquefaciens suppressing Rhizoctonia solani. Soil Biol. Biochem., 2002, 34: 955-963 (doi: 10.1016/S0038-0717(02)00027-5).

25. Shrest ha A., Sult a na R., Cha e J.-C., K i m K., Le e K.J. Bacillus thuringiensis C25 which is rich in cell wall degrading enzymes efficiently controls lettuce drop caused by Sclerotinia minor. Eur. J. Plant Pathol., 2015, 142: 577-589 (doi: 10.1007/s10658-015-0636-5).

26. Hathout Y., Ho Y., Ryzhov V., De mi rev P., Fense la u C. Kurstakins: a new class of lipopeptides isolated from Bacillus thuringiensis. J. Nat. Products, 2000, 63: 1492-1496.

27. K i m P.I., B a i H., B a i D., Cha e H., Chung S., Ki m Y., Park R., Chi Y.-T. Purification and characterization of a lipopeptide produced by Bacillus thuringiensis CMB26. $J$. Appl. Microbiol., 2004, 97: 942-949 (doi: 10.1111/j.1365-2672.2004.02356.x).

28. Ste in T. Bacillus subtilis antibiotics: structures, syntheses and specific functions. Molecular Microbiology, 2005, 56(4): 845-857 (doi: 10.1111/j.1365-2958.2005.04587.x).

29. Z h o u Y., Choi Y., S u n M., Y u Z. Novel role of Bacillus thuringiensis to control plant diseases. Appl. Microbiol. Biotechnol., 2008, 80(4): 563-572 (doi: 10.1007/s00253-008-1610-3).

30. K i m P.I., R y u J., K i m Y.H., C h i Y.-T. Production of biosurfactant lipopetides Iturin A, fengycin and surfactin A from Bacillus subtilis CMB32 for control of Colletotrichum gloeosporioides. J. Microbiol. Biotechnol., 2010, 20(1): 138-145.

31. Yánez-M endizábal V., Zeriouh H., Viñas I., Torres R., Usall J., de Vicente A., Pérez-García A., Teixidó N. Biological control of peach brown rot (Monilinia spp.) by Bacillus subtilis CPA-8 is based on production of fengycin-like lipopeptides. Europ. J. Plant Pathol., 2012, 132: 609-619 (doi: 10.1007/s10658-011-9905-0).

32. Elkahoui S., D jébali n N., Karkouch I., Hadj Ibrahim A., Kalai L., B a chkoue 1 S., T abben e O., Li ma m F. Mass spectrometry identification of antifungal lipopeptides from Bacillus sp. BCLRB2 against Rhizoctonia solani and Sclerotinia sclerotiorum. Appl. Biochem. Microbiol., 2014, 50(2): 161-165 (doi: 10.1134/S0003683814020082).

33. A s s a t u rova A.M. Perspektivnye shtammy bakterii - produtsenty mikrobiopreparatov dlya snizheniya vredonosnosti fuzarioza na podsolnechnike. Avtoreferat kandidatskoi dissertatsii [Promising bacterial strains as producers for the microbiologicals effective against Fusarium fungi in sunflower. PhD Thesis]. St. Petersburg-Pushkin, 2009.

34. Ka me nek L.K., Ka menek D.V., Tyul'pi neva A.A., Terpilovski i M.A. Biotekhnologiya, 2008, 5: 76-83.

35. Kandybin N.V., S mirnov O.V., B a rbas hova N.M. Materialy Vserossiiskogo nauchno-prakticheskogo soveshchaniya [Proc. All-Russia Meeting]. Pushchino, 1994: 179-181.

36. Grish e chkina S.D., S mi r nov O.V., K a n d y b n N.V. Mikologiya $i$ fitopatologiya, 2002, 36(1): 58-62.

37. Ko tova V.V. Metodicheskie ukazaniya po izucheniyu vredonosnosti kornevoi gnili yarovoi pshenitsy i yachmenya i metody rascheta poter' ot boleznei [Estimation of damage from root rot in spring wheat and barley with calculation of losses: recommendations]. Leningrad, 1979.

38. Sidorova S.F., Popov V.I. Metodicheskie ukazaniya po izucheniyu vertitsilleznogo $i$ fuzarioznogo uvyadaniya sel'skokhozyaistvennykh rastenii [Study of Verticillum and Fusarium wilt in cultivated plants: guidelines]. Leningrad-Pushkin, 1980.

39. Vlas ov Yu.I., Gavrilova E.A., Minkevich I., Chu makov A.E. Osnovnye metody fitopatologicheskikh issledovanii [Basic methods of phytopathology]. Moscow, 1974.

40. Los hak ova N.I., K ry lova T.V., Kudryavt s e va L.P. Metodicheskie ukazaniya po fitopatologicheskoi otsenke ustoichivosti l'na-dolguntsa $k$ boleznyam [Phytopathological estimation of flax plants resistance to diseases: guidelines]. Torzhok, 2006.

41. Tupenevich S.M., Khokhryakov M.K., Chumakov A.E. Rekomendatsii po bor'be s kornevymi gnilyami pshenitsy $i$ yachmenya [Wheat and barley protection measures against root rots]. Leningrad, 1962.

42. Metodicheskie ukazaniya po otsenke selektsionnogo materiala na ustoichivost' $k$ fitoftorozu, 
rizoktoniozu, bakterial'nym boleznyam i mekhanicheskim povrezhdeniyam [Estimation of breeding material on resistance to blight, sheath blight, bacterial diseases and mechanical damage: guidelines]. Moscow, 1980.

43. Smirnov O.V., Borodavko N.B., Grishechkina S.D. Tezisy dokladov 1-go Vserossiiskogo s"ezda po zashchite rastenii [Proc. $1^{\text {st }}$ All-Russia meeting on plant protection]. St. Petersburg, 1995: 367-368.

44. S mirnov O.V. Patotipy Bacillus thuringiensis i ekologicheskie osnovy ikh ispol'zovaniya v zashchite rastenii. Avtoreferat doktorskoi dissertatsii [Bacillus thuringiensis pathotypes and ecological bases for their use in plant protection. DSc Thesis]. St. Petersburg-Pushkin, 2000.

45. Grishechkina S.D. Materialy Mezhdunarodnoi nauchno-prakticheskoi konferentsii «Agrotekhnicheskii metod zashchity rastenii» [Proc. Int. Conf. «Agrotechnologies for plant protection»]. Krasnodar, 2013: 313-316.

46. G ris he ch k i n a S.D., K u z net s o va A.V. Zashchita i karantin rastenii, 2012, 3: 28-29.

47. Anisimov A.I., Dobrokhotov S.A., Grishechkina S.D. Materialy Mezhdunarodnoi konferentsii «Infektsionnaya patologiya chlenistonogikh» [Proc. Int. Conf. «Infectious diseases in arthropods»]. St. Petersburg-Pushkin, 2012: 9-11.

48. Kandybin N.V., S mi rnov O.V., Grishechkina S.D., S tolova O.V., Kra s a vi n a L.P. Materialy VII s"ezda Rossiiskogo entomologicheskogo obshchestva [Proc. VII meeting of Russian Entomological Society]. St. Petersburg, 1997: 177-178.

49. Gris he chkin a S.D., S m i r nov O.V., K a nd y bi n N.V. Tezisy dokladov 2-go Vserossiiskogo s"ezda po zashchite rastenii [Proc. $2^{\mathrm{d}}$ All-Russia meeting on plant protection]. St. Petersburg, 2005: 155-157.

50. G ris he c h k i n a S.D., S m i r no v O.V. Vestnik zashchity rastenii, 2010, 3: 44-50.

51. Grishechkin a S.D., Loshakova N.I. Agro XXI, 2013, 10-12: 18-19.

52. G r i s h e c h k i n a S.D. Materialy Mezhdunarodnoi nauchno-prakticheskoi konferentsii «Zashchita rastenii $v$ sovremennykh tekhnologiyakh vozdelyvaniya sel'skokhozyaistvennykh kul'tur» [Proc. Int. Conf. «Plant protection in current crop cultivation»]. Krasnoobsk, 2013: 112-114.

53. Tsvetkova V.P., Shternshis M.V., Grishechkina S.D. Mat. Mezhd. nauch.prakt. konf. «Innovatsionnye tekhnologii primeneniya biologicheskikh sredstv zashchity rastenii v proizvodstve organicheskoi sel'skokhozyaistvennoi produktsii» [Proc. Int. Conf. «Innovations in use of plant protecting biologicals in organic agriculture»]. Krasnodar, 2014: 301-305. 